\title{
Editorial
}

\section{Private Medical Colleges in Bangladesh}

Medical profession is still the most sought profession in our country. Thousands of brilliant students after passing Higher Secondary School Certificate Examination opt for admission for medical graduation. But most of them are unable to get admission in government medical colleges because of limitation in the number of the seats. Therefore, to fulfill the demand of these brilliant students and also to overcome the shortage of doctors in the country, medical colleges in the private sector in Bangladesh are much needed. Realizing this necessity of private sector medical colleges in Bangladesh, Bangladesh Medical College was allowed to start its functioning in 1986 and henceforth more than half-a-hundred of private medical colleges have so far been established in the country and more are in the pipeline.

Establishment of medical colleges is very expensive and difficult. It is not like the establishment of other type of academic institutions. Bangladesh Medical and Dental Council (BMDC), Universities to which the medical colleges are affiliated and Ministry of Health \& Family Welfare have laid down certain requirements for establishment of medical colleges. But unfortunately in spite of tight roping by these regulatory authorities, many of the private medical colleges (also some of the government medical colleges) are not up to the mark. Why? We need to find out the reasons behind and must solve them. If we can do it, private sector medical colleges have great future and some may become famous, outstanding and centres of excellence (may be like the private sector medical schools in USA). It can also be a source of earning currency in dollar that our economy needs badly.

Already mentioned, Bangladesh Medical College is the first in our country in the private sector. It was established in 1986 (classes of first batch commenced from July 1987) by a group of dedicated people who were imbued with the ideas of providing quality medical education, research and service to people at a reasonable cost. ${ }^{1}$ It has done reasonably well and earned a good reputation for its standard of medical education and health care services. But still it has scopes to make further progress to the trajectory of excellence. Many other medical colleges in private sector have made good progress, but still there are a lot of things to improve to become centres of excellence. Most of the medical colleges in private sectors need to elevate the standard in terms of education and hospital facilities.

BMDC is the statutory body of the government entrusted with the responsibilities for maintaining the standard of medical education and health care services in the country. Ministry of Health \& Family Welfare and affiliating Universities also play significant role in this regard. There are some guidelines regarding the number of teachers and other staff required in each subject based on the number of admission in a college each year, the space for the college, its administration, basic departments and hospital facilities. Lecture halls, laboratories, demonstration room, dissection hall, the library, the museums, hostels, equipments needed in each department, hospital beds - all are described in the guidelines. Inspection teams from the regulatory authorities are inspecting medical colleges from time to time and justifying whether the requirements are fulfilled and standard of education is up to the mark. In spite of all these measures, medical education in the private sector (also in government sector) is not up to the mark. Why? What are the reasons behind? Is there any fault in inspection or decision making? It is to be found out honestly and solved accordingly.

Medical colleges are not like colleges of general education. Most medical colleges are larger than many universities. In addition to imparting education to students, medical colleges both in public and private sectors have to establish hospitals and are to provide health care services. Enough patients both in indoor and outdoor are a must in these hospitals. Students develop their clinical expertise when they are placed in different hospital wards from $3^{\text {rd }}$ year. Well-equipped operation theatres with all the modern facilities, improved diagnostic services etc.- all these are essential. Many medical colleges in private sector (and also some medical colleges in public sector) 
lack these facilities and so students are being deprived from developing themselves clinically. We believe, a well established at least 250-bed hospital with sufficient patients should be the basic requirement along with others to get approval for a medical college. After passing the $1^{\text {st }}$ professional examination students are placed in clinical wards. But during this short period, it is not at all possible to establish a hospital with required facilities and sufficient patients.

Admission of students into the private medical colleges is still a problem. Most of the private medical colleges, especially the peripheral ones are not getting good quality students. Ways are to be sorted out for good students. Raising the minimum GPA scoring for admission into medical colleges may be considered.

Research activities is a neglected corner in our medical institutions - either government or private. A research cell should be mandatory in all medical institutions to conduct basic and applied research. Research works may involve public health, clinical research, biochemistry, biotechnology, microbiology, physiology, oncology, surgery, noncommunicable diseases etc.

Throughout the world, most of the top medical colleges and schools are in private sector. ${ }^{2,3}$ Harvard, Johns Hopkins, Stanford, Yale, Cornell, Columbia, Mayo etc are the best examples. Many students dream to study in these institutions in spite of heavy expenses there. Harvard Medical School is currently ranked first among American research medical schools by US News and World report. ${ }^{4}$ We also should be ambitious and courageous to reach the peak of the success in the medical sector regarding education, research and health care services.

\section{Md. Aminul Haque Khan}

\section{Professor}

Department of Biochemistry

Enam Medical College, Savar, Dhaka

Email: aminhkhan@yahoo.com

\section{References}

1. 'Bangladesh Medical College', Available at: http:// www.bmc-bd.org/about_bmc.php. Accessed October 2011.

2. Khan AJ, 'Scope of medical colleges in private sector', Available at: http://www.ayubmed.edu.pk/JAMC/ PAST/ 16-1/AJ Khan.htm. Accessed October 2011.

3. 'Frontier Medical College Abbottabad, Pakistan', Available at: http://www.fmc.edu.pk/aboutus.php. Accessed October 2011.

4. 'Harvard medical school', Available at: http://en. wikipedia.org/wiki/Harvard_Medical_College. Accessed October 2011. 